College of Agriculture; Dr. G. A. Reay, of the Torry Research Station, Aberdeen; Mr. E. R. H. Edge, of Messrs. Alex. Pirie and Co., Aberdeen, on paper-making ; Prof. W. H. Melville, of the University of Aberdeen, on rubber; Dr. I. A. Preece, of the Heriot-Watt College, Edinburgh, on brewing; and Mr. H. Corteen, director of the British Jute Trade Research Association of Dundee, will speak on "Research Developments and Applications to Textile Industries in East Central Scotland". The meeting is being organised by the Edinburgh and East of Scotland Section of the Society, the honorary secretary of which is F. J. Bolton, 17 Wester Coates Avenue, Edinburgh 12.

\section{International Conference on Powder Metallurgy}

THE Steirmark Branch of the Association of Austrian Chemists is arranging an International Powder Metallurgy Conference to be held during July 12-16 in Graz. It is hoped, by lectures and discussions, to furnish a comprehensive picture of the position and problems of the scientific, industrial and economic aspects of powder metallurgy and allied subjects. The organising committee consists of Prof. G. Jantsch, Technische Hochschule, Graz; Dr. R. Kieffer, Metallwerk Plansee, Reutte, Tirol ; Prof. O. Kratky, Universität, Graz; Prof. G. F. Hüttig, Technische Hochschule, Graz. Further information can be obtained from Dr. C. Sykes, Brown - Firth Research Laboratories, Princess Street, Sheffield ; or Mr. M. Littman, Compound Electro Metals, Ltd., 42 Pall Mall, London, S.W.1.

\section{International Sericultural Congress}

The Seventh International Sericultural Congress will be held at Alès (Gard) in the Cevennes during June 7-13, and will be followed by an International Silk Congress at Lyons. The Sericultural Congress is being organised by the French National Institute of Agronomic Research; the president is Prof. R. Delmas, professor of sericulture in the École Nationale d'Agriculture, Montpellier, and the general secretary is M. Schenk, director of the Sericulture Research Station, Alès. The programme is being arranged in a number of sections covering scientific, economic and technical aspects of the subject. The Congress, which will mark the fiftieth anniversary of the research station at Alès, will be the first of so wide a scope since the Sixth International Sericultural Congress held in Paris during September 1878. Further particulars can be obtained from the Secrétariat-Général, Station de Recherche Séricoles, 28 Quai Boissier de Sauvages, Alès (Gard), France.

\section{Conference on Rheology and Textiles}

A Conference on "Rheology in the Textile Industries" has been arranged by the British Rheologists' Club in association with the Textile Institute, the Society of Dyers and Colourists, the Leeds area local sections of the Chemical Society and the Royal Institute of Chemistry, the Yorkshire Section of the Society of Chemical Industry and the Manchester and District Branch of the Institute of Physics, and will be held during March 19-20 in the Department of Textile Industries, University of Leeds. Further particulars can be obtained from Prof. J. B. Speakman, University, Leeds 2, or the honorary secretary of the British Rheologists' Club, Dr. E. W. J. Mardles, Royal Aircraft Establishment, Farnborough, Hampshire.

\section{Announcements}

AT a recent ceremony at the Royal Netherlands Embassy, London, the Netherlands Ambassador presented the insignia of Commander in the Order of Orange-Nassau (Civilian Division) in recognition of services rendered to the Netherlands during the War to the following, among others : Sir George Beharrell, chairman of the Dunlop Rubber Co., Ltd. ; Sir Jack Drummond, sometime scientific adviser to the Ministry of Food; Dr. John Hammond, reader in agricultural physiology, University of Cambridge; Sir Raymond Streat, chairman of the Cotton Board.

THE following appointments in the University of Leeds have been announced: Prof. H. S. Ruse, professor of pure mathematics, to be head of the Department of Mathematics on the retirement of Prof. S. Brodetsky at the end of the present session; Prof. T. G. Cowling, professor of mathematics at the University College of North Wales, Bangor, to be professor of applied mathematics from October 1 ; Dr. N. H. Hartshorme, to be lecturer in chemical microscopy.

THe following appointments in the University of Sheffield have been announced: Dr. A. J. Gould, senior lecturer in the Department of Glass Tech. nology ; Dr. J. S. D. Bacon, lecturer in biochemistry ; R. E. Davies, honorary lecturer in biochemistry; A. Jordan, honorary lecturer in elinical biochemistry.

A sxmposrum on "Combustion and Flame and Explosion Phenomena" will be held at the University of Wisconsin during September 7-11. Papers will be presented on fundamental and theoretical aspects of combustion, technical research, combustion prob. lems in jet propulsion, special fuels, etc. It is hoped to publish all the papers together within a few months of the meeting. Particulars can be obtained from Prof. Joseph O. Hirschfelder, University of Wisconsin, or from Dr. Bernard Lewis, U.S. Bureau of Mines, Pittsburgh 13, Pennsylvania.

THE Faraday Society is arranging one of its General Discussions, which will be held in the Department of Physies, University College, Southampton, during March 31-April 2. The subject will be "The Interaction of Water and Porous Materials", and the papers have been divided into four groups : (1) Funda. mental Aspects ; (2) Botanical Aspects : Mechanism of Movement of Solutions in Plants ; (3) Zoological Aspects: Water-Protecting Properties of Cuticles; and (4) Permeability to Water and Water Vapour of Textiles and other Fibrous Materials. Papers will be issued in advance of the meeting and taken as read. Further particulars can be obtained from the Faraday Society, 6 Gray's Inn Square, London, W.C.1.

The British Iron and Steel Research Association has now obtained a licence for erecting limited accommodation of temporary construction on a site at Meadow Street in Sheffield. At the present time the Association's investigations at Sheffield are divided between the Applied Science Department of the University of Sheffield (where there is an experimental rolling mill), the works of Arthur Lee and Sons, Ltd. (where there is a prototype backpull wire drawing machine), and elsewhere. The intention is ultimately to create a permanent building in which rolling, drawing and other similar researches will be centralized. 